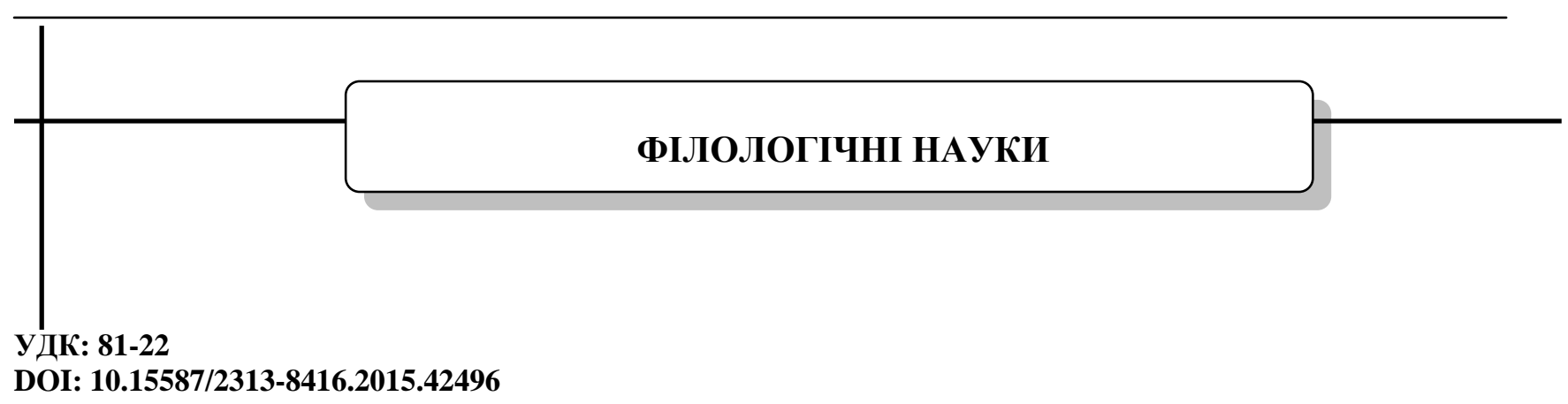

\title{
PECULIARITIES OF SCIENTIFIC STYLE IN SCIENTIFIC CHEMICAL TEXTS
}

\author{
(C) S. Bobrovnyk
}

The article deals with the peculiarities of scientific style in chemical texts. Brief framework of scientific style is given. The main features of scientific chemical texts are defined. The structure of scientific texts, its syntax and grammar structures, usage of terms and formulas, logical sequence, accurate information, real data, cause-andeffect relationship and perceptions are outlined

Keywords: genre, peculiarities, style, thesis, abstract, structure, scientific, analysis

Стаття присвячена особливостям наукового стилю в текстах з хімії. Надана коротка характеристика наукового стилю властивого текстам з хіміі. Відмічені особливості написання наукових хімічних текстів, їх структура і притаманні иьому стилю граматичні структури, синтаксис, використання термінів і формул, логічна послідовність, лаконічність, подача точної інформації, реальні дані, причинно-наслідкові зв'язки та твердження.

Ключові слова: жанр, особливості, стиль, теза, анотація, структура, науковий, аналіз

\section{Introduction}

Genre is a form of organization of speech material in the frame of this or that style of speech. In terms of genres, scientific speech is one of the richest diversities of speech. Genre diversity of scientific style is stipulated most of all by the presence of a great number of different types of texts. There is the following functional-style classification of scientific style of speech: scientific, scientifically-informative; proper research, finding. According to the classification of scientific style there is a description of scientific texts of different genres which correspond to the variety of scientific style. Among the genres of scientific style we can distinguish scientific: monographs, articles, reports, course works, bachelor's thesis, master's thesis; scientific-informative: abstract, annotation, synopsis, notes, patent specification; scientificinquiry: dictionary, catalogue, and reference-book; educational: textbook, dictionary, lecture, notes, learner's guide, annotation, oral answer, explanation; popular science: books, lectures, articles, essays.

\section{Aim}

The aim of this article is to highlight the peculiarities of scientific chemical texts, to outline the main principles of writing scientific papers, abstracts, reports, etc. The topicality of this topic is stipulated by the need of correct writing of scientific chemical papers taking into account the fact that scientific style is accurate, laconic, logical and full of facts with the definite structure of writing which are typical of scientific chemical texts.

\section{Literature review}

Scientific texts of different genres are built according to one logical scheme. The main thesis - asser- tion that is in the basis of this scheme, this thesis requires foundation; the thesis includes the subject of the speech (something that is in question in the certain text) and the main indication which is analyzed (something that says about this subject). The evidence of the main thesis is the argument (proofs, foundations), the quantity of which depends on the genre and volume of the scientific text. Illustrations - examples which confirm the theoretical provisions are needed for the full argumentation. Scientific chemical papers and monographs are original works of research character which belong to the scientific style. They are so-called primary genres of scientific style, as they are written by the specialists and for the specialists. Scientific paper is an essay of a small size where the author sets forth the results of his research. Monograph is a scientific work, a book dedicated to the study of one problem. Reports, theses and course works relate to this group of genres. Texts of these genres must possess the properties which are typical of scientific texts; they must be accurate, logical, generalized with strong composition. These genres have common properties; they are compiled on the basis of the data, supportive texts, mostly original, primary, though theses can be original scientific work and can relate to educative-scientific variety of scientific style of speech. \section{arities}

\section{Structural, grammatical and stylistic peculi-}

In all scientific chemical texts the following structural semantic components are distinguished: the name (heading), introduction, main body and conclusion.

The name (heading) of the scientific text is an important information unit reflecting the topic of certain 
work and corresponds to the content of the text. There are several types of headings:

- the name of general character (introduction into terminology);

- the name which concretizes the questions of the scientific theory and practice developed by the author;

- the name which reflects the peculiarities of the author's statement of the question.

Introduction is brief and accurate where the topic of the research is substantiated, the research methods are described; aims and tasks are formulated. For example, this is the introduction from the scientific article:

"Introduction. Practical jet fuels, i.e., those fuels derived from the refinery processing of crude petroleum are chemically complex, often containing thousands of compounds. Because these fuels must meet broadly defined specifications, their composition varies not only with refinery and crude oil source but also with season and year of production. Moreover, composition changes as the fuel ages. As a result, it is difficult to control the consistency in fuel composition required for the purpose of research. The use of surrogate blend, comprised of a relatively small number of high purity hydrocarbons and blended to simulate the combustion performance of practical fuel, has the advantage of allowing fuel composition to be accurately controlled and monitored. In addition to providing a model fuel for the study of the effect of fuel properties and chemical composition on combustor performance, the compositional control afforded by a surrogate fuel is attractive for the development and verification of computational codes for combustor design. ..." [2].

The main goal of any branch of science is the disclosure and research of the regularities of the phenomena and processes. Among the aims of any scientific research there must be the disclosure of the specific character of the scientific object, creation of typology, explanation of the phenomena, description of functions, systematization and generalization of the facts etc. The main part of the monograph and coursework is divided into chapters in accordance with the tasks and volume of the work. The chapters of the scientific articles are not distinguished, but every new scientific provision is formed into a new paragraph.

The scientific chemical text is completed with a resume or conclusion where one can find analytical assessment of the conducted research, and the prospectives of the further search are defined. The conclusion contains statements of the certain research or has the form of a brief resume.

Abstracting is an intellectual creative process including comprehension of the text, transformation of information by analytical and synthetic means and creation of a new (secondary) text. Abstract is an adequate summary of the original text. It reflects the main information which can be found in the original text, new information, and essential data. Preparation of abstracts is one of the most difficult types of individual work. Abstracting teaches a learner to work with literature deliberately, to orientate in it choosing necessary information. The abstract must be informative; it should transfer the content of the original text objectively, to evaluate the material correctly. The abstract can be reproductive, reproducing the content of the original text and productive containing critical and creative deliberation of the abstracting source. Reproductive abstracts can be of two types: abstract-synopsis and abstract-resume. Abstract-synopsis contains factual information in general way, illustrative material, data about techniques of research gained from the results and opportunities of their implementation. Abstract-resume gives only the main provisions which are closely connected with the topic of the text. Productive abstracts are presented as abstracts-reviews or abstracts-reports. Abstract-review is compiled on the basis of several original texts, it provides with comparison of different points of view about the certain question.

Abstract-report has a detailed full-scaled character, along with the analysis of information; it gives objective assessment of the problem's state. In the structure of any abstract three main components are defined:

- bibliographic description;

- abstract text itself;

- finding aid.

Like any scientific chemical text, abstract has a certain composition:

1. Introduction. Entry tasks are as follows: to give the original text's data (the name of the source-text which was published and when it was published), to provide information about the author (surname, first name, specialty, academic degree, academic rank), to reveal the meaning of the name of the work in connection with what it is written.

2. Enumeration of the main question and problems which are mentioned in the original source.

3. Analysis of the most important things according to the reviewer, the questions contained in the source text. Through this analysis, it is necessary to justify the importance of the selected issues briefly and to convey the author's opinion on these matters, to express the opinion on the author's judgment of the information-source.

4. The general conclusion about the meaning of the entire topic or the problem abstracted in the text [7].

Kotyurova M. described scientific style as a style of literary language which has some peculiarities, such as preliminary deliberation of the utterance, monologue character, strict choice of the language means, and inclination to standardized speech. Logicality, strict emphasis on summary, accuracy, clarity, objectivity, abstractiveness, generality, conciseness of summary, intellectuality and others are typical for scientific style. Scientific style is not a fad, but an obligation. Among scientists and researchers it is accepted that all scientific texts should be written in a certain strict style. It is done, above all, by the need to avoid ambiguity and ambiguities of certain scientific concepts. The style of the research papers is ultimately determined by their content and goals of scientific communication, i.e. to express the facts accurately and fully explain the facts, to show cause-and-effects relationships between the events, to identify regularities of historical development and so on [4].

The original form of scientific speech existence is written form of speech as conceptual reflection of reality, logical presentation. According to Prohorova K. V., scientific speech should be strictly evidential and wellreasoned. Disputes of scientific topics and first-hand dis- 
cussion of some aspects are very important, but mostly information transmission is orientated to the written speech (writing formulas, demonstration of tables, graphs, etc.). Indeed scientific exposition, no matter how important oral debates on scientific subjects, direct discussion of certain aspects or performance, largely still focused on written language, as clearly evidenced by the need in many cases at least a partial transition to the elements of a written statement (writing formulas demonstration tables, charts, etc.), e. g. [5].

"...Why does the presence of $\mathrm{Cr}_{2} \mathrm{O}_{3}$ in $\mathrm{Al}_{2} \mathrm{O}_{3}$ make a ruby red? The Cr3 (3 в числитель или в знаменатель или так оставить я не знаю) ion absorbs yellow-green colors from white light striking the ruby, and the remaining red-blue light is transmitted, resulting in a deep red color. This same process occurs in all gems..." [1].

The concepts which operate the scientific thinking are usually expressed in a multicomponent structure, typical for writing. This is because the written form is more convenient and secure in the sense of detecting the slightest inaccuracy in the information or logical disorders that are not relevant to everyday communication, but in scientific communication it can lead to the most serious distortions of the truth.

Terms are often used in scientific speech. Term is a word or word-combination defining the notion of the certain sphere of knowledge or activity and is the element of the certain system of terms. In this system the term is aimed at unambiguity, it is not expressive and neutral [6].

Terms as the main lexical constituents of scientific style are used in one defined meaning. For example:

Polystyrene manufacturers phased out the use of chlorofluorocarbons (CFCs) in the late 1980s because of concerns about the ozone layer. [4].

If the word is polysemantic it is used only in one meaning, rarely in two meaning which are terminological, e. g. size, dimension, movement, solid, sour, body, etc.

Scientific style is characterized by special usage of some verbal categories which are also peculiar to chemical texts. The Present Simple Passive is often used. For example, chloride is slowly decomposed; carbon is the most important part of the plant, the logs are stripped of bark, the chips are put into a large tank, the pulp is drained of water, the voltage is applied, the magnetic field is set up. [3]

Abstractiveness and generality of scientific speech are expressed in frequent usage of abstract nouns such as movement, amount, phenomenon, attitude, action, property, formation, change, arrangement, distribution, state, effect, meaning, definition, experience, process, question, volume, character, period, technique, method, etc.

Syntax of scientific style is characterized by the tendency to complex constructions that facilitate the transmission of complicated system of scientific notions and establishing the cause-and-effect bonds, proofs and conclusions. Sentences with homogeneous members and resumptive words are often used too. Clear separation of paragraphs helps to emphasize the logical aspect of the speech. Efficient consolidation of definite sentences into complex syntactic units serves the same aim. Clichés are used in scientific papers of popular science character in the form of special lexis, e. $\mathrm{g}$.

The article is headlined ...; As the title implies the article describes ...; The main (basic) idea of the article is ...; The article touches upon...; It is spoken in detail ...; Much attention is given (paid) to ...

Functional words such as: on, upon, in, after, before, besides, instead of, in preference to, apart (aside) from, except (for), save, in addition (to), together with, owing to, due to, thanks to, according to, because of, by means of, in accordance play a significant role in scientific texts; they create logical bonds play a significant role in scientific style. Usually research reports and messages are written processing the adequate form of scientific information embodiment or at least theses or a plan are compiled. The texts of scientific style of speech can contain not only the linguistic information, but also a variety of formulas, symbols, tables, graphs, etc. To a large extent this applies to texts of natural and applied sciences: mathematics, chemistry, physics and others. Almost any scientific text can contain graphic information; this is one of the significant features of scientific style of speech.

\section{Conclusion}

The sphere of scientific communication is defined by logical expression of ideas and thought. The main form of thinking in science is deliberation, dynamic of thinking that is expressed in judgements and conclusions which follow each other in a strict logical sequence. The final crystallization of the scientific thought is realized in oral and written texts of different genres of scientific speech. Saturation of factual information is necessary for the validity and objectivity of the presentation. Thus, we can say that the language of scientific chemical texts is very different from the language of the other styles of speech. The main reason is that the purpose of scientific presentation is to influence the mind, not the feelings of the reader, and the communication of information in an objective description. Thus, logical sequence, accurate information, real data, proved assertions, clear separation of paragraphs, correct usage of terms are distinguished among the main peculiarities of scientific chemical texts.

\section{References}

1. Buthelezi, T. Chemistry. Matter and Change [Text] / T. Buthelezi, L. Dingrando, N. Hainen, C. Wistrom, D. Zike. New York: McGraw-Hill, 2008. - 1008 p.

2. Kyungchan, C. Thermal Decomposition of Decalin. An Initial Study [Text] / C. Kyungchan, A. Violi. - The University of Michigan, 2006. $-7 \mathrm{p}$.

3. Brieger, N. Technical English Vocabulary and Grammar [Text] / N. Brieger, A. Pohl. - Summertown Publishing, 2007. $-148 \mathrm{p}$.

4. Kotyurova, M. Textbook for University Students [Text] / M. Kotyurova. - M: Akademia Publishers, 2010. - 240 p.

5. Prohorova, K. Scientific style: textbook for studentsjournalists [Electronic resource] / K. Prohorova. - R: SPSU, 2008. - Available at: http:// rus.if.spbu.ru/medialingvistika

6. Prohorova, V. Russian terminology (lexical-semantic formation) [Text] / V. Prohorova. - M.: MSU, 1996. - 126 p.

7. Writing of abstracts. [Electronic Resource] / Available at: http://en.wikipedia.org/wiki/Abstract_\%28summary\%29 
References

1. Buthelezi, T., Dingrando, L., Hainen, N., Wistrom, C., Zike, D. (2008). Chemistry Matter and Change. Third edition. New York, USA: McGraw-Hill, 1008.

2. Kyungchan, C., Violi, A. (2006). Thermal Decomposition of Decalin. An Initial Study. UK: The University of Michigan, 7.

3. Brieger, N., Pohl, A. (2007). Technical English Vocabulary and Grammar. UK: Summertown Publishing, 148.
4. Kotyurova, M. (2010). Textbook for University Students. Moscow: Akademia Publishers, 240.

5. Prohorova, K. (2008). Scientific style: textbook for students-journalists. R: SPSU. Available at: http://rus.if.spbu.ru/ medialingvistika

6. Prohorova, V. (1996). Russian terminology (lexicalsemantic formation). Moscow: MSU, 126.

7. Writing of abstracts. Available at: http://en.wikipedia. org/wiki/Abstract_\%28summary\%29

Рекомендовано до публікації д-р філол. наук Іщченко Н. Г. Дата надходження рукопису 22.04.2015

Bobrovnyk Svitlana, teacher of English, Department of English language of technical orientation, Faculty of Linguistics, National Technical University of Ukraine "Kyiv Politechnic Institute", Pobedy ave., 38, Kyiv, Ukraine, 03056

E-mail: cindsv@mail.ru

УДК 82. 09 М. Коцюбинська

DOI: $10.15587 / 2313-8416.2015 .42788$

\title{
НОНКОНФОРМІСТСЬКИЙ ДИСКУРС ЛІТЕРАТУРНО-КРИТИЧНОЇ ДІЯЛЬНОСТІ МИХАЙЛИНИ КОЦЮБИНСЬКОї
}

\author{
(C) С. Г. Бугай
}

У статті розглядається своєрідність науково-критичної рецепиії історї й теорії украӥнської літератури в студіях Михайлини Коцююбнської. Детально проаналізовано наукові підходи і погляди літературознавия в інтерпретації ключових проблем художнього дискурсу: особливостей жанрово-тематичної, композиційної структури, образно-стильової палітри письма, специфіки художнього мислення письменника, морально-етичних та філософських засад творчості, своєрідності асочіативних зв'язків, осмислення художньої спадщини в контексті доби

Ключові слова: рецееція, автор, читач, історія, теорія, текст, стиль, жанр, композичія, творчість

The peculiarity of scientific and critical reception of history and theory of Ukrainian literature in studios of Mykhaylyna Kotsiubynska is considered in the article. It is given the detailed analysis of scientific approaches and attitudes in literary interpretation of the key issues of artistic discourse: features of genre-thematic, compositional structure, imagery and stylistic palette of writing, specific of writer's artistic thinking, ethical and philosophical foundations of creativity, originality of associative relationships, understanding artistic heritage in the context of the time

Keywords: reception, author, reader, history, theory, text, style, genre, composition, creativity

\section{1. Вступ}

В осмисленні сучасного літературного процесу літературознавство і критика відіграють особливо важливу роль. Вони допомагають орієнтуватися в складній системі сучасних літературознавчих ідей, методів дослідження, критичних підходів. Вбираючи у себе найрізноманітніші антропологічні, лінгвістичні, філософські, природничонаукові вчення, сучасне літературознавство перетворилось у розгалужену і автономну систему гуманітарного знання. Теоретичні проблеми літературнохудожньої критики набувають дедалі більшої наукової і суто прикладної значущості. Професійна діяльність літературознавців виступає одним із показників культурного рівня розвинутих країн. Саме тому зростає потреба поглибленого вивчення творчого доробку цілого ряду постатей, які були безпосередніми творцями і водночас дослідниками літературного процесу XX - початку XXI століття.
Михайлина Хомівна Коцюбинська (19312011) - відомий літературознавець, критик, спадкоємиця славного роду Коцюбинських, одна з відомих діячів руху шістдесятників, чий духовний світ, засадничі світоглядні домінанти викристалізовувались у нелегких умовах тоталітарного суспільства. Переживши моральні випробування, допити й обшуки, замовчування імені, табу на літературознавчі дослідження, уже в часи свого наукового визнання вона скаже: «Попри все я вдячна долі!».

Народжена в інтелігентній родині та названа на честь уславленого дядька - класика української літератури Михайла Коцюбинського, майбутня вчена разом $з$ уславленим іменем успадкувала «родові гени національної самосвідомості, незалежності думки, співчуття до скривджених» [1], високість духу, основні заповіти, ідеали й цінності письменника. Зростаючи в атмосфері любові та поваги до слова, позначеній частими і плідними зустрічами з непересічними 